\title{
The Nature of Shoot Dominance in White Yam Tubers (Dioscorea rotundata Poir) ${ }^{1}$
}

\author{
Osi Mozie ${ }^{2}$
}

\begin{abstract}
The nature of shoot dominance in white yam tubers (Dioscorea rotundata Poir) was studied under ambient conditions in the conventional yam storage barn. Whole tubers sprouted only at the proximal ends (i.e. the morphological bases). The single basal shoot formed per sprouting whole tuber inhibited the formation of lateral shoots along the tuber axis. Separating the basal end by sectioning the tuber into three regions namely "head" (i.e. basal or proximal region), middle region and "tail" (i.e. apical or distal region), appeared to stimulate the formation of lateral shoots on the surfaces of the tuber pieces below the basal region. Separating the basal region from the entire tuber by sectioning appeared to remove the stress under which the lateral buds had existed in the intact tuber. This response indicated a strong "basal dominance" of basal shoots in sprouting intact or whole yam tubers.

The physiology of shoot dominance in whole yam tubers could be described as "basal dominance" rather than "apical dominance", since in sprouting intact or whole tuber it is the basal shoot (i.e. shoot of the morphological base or proximal end) that inhibits the development of lateral shoots along the tuber axis.
\end{abstract}

\section{INTRODUCTION}

Yams (Dioscorea spp) of the tropics are climbing monocotyledonous vines with large strong underground tubers. Sizes of individual tubers may range from a few grams to over $50 \mathrm{~kg}$, and tuber lengths of 2 to $3 \mathrm{~m}$ have been recorded. ${ }^{3}$ Yam tubers are more or less cylindrical in shape and covered by a thick layer of cork.

Yams, especially white yams (D. rotundata Poir.), serve as staple foods in West Africa. It is also extensively produced in the West Indies. Figure 1 shows the general morphology of the yam tuber. The morphological apex (i.e. distal region or "tail") is the growing region of the yam tuber. The opposite end of the tuber is the morphological base (i.e. proximal region or "head").

While potato tubers (Solanum tuberosum) exhibit true apical dominance, ${ }^{4}$ it is doubtful, in the opinion of the author of this paper, if yam tubers can be said to exhibit apical shoot dominance. Coursey ${ }^{3}$ and Passam ${ }^{5}$ maintain that sprouting of yam tubers is under the influence of

${ }^{1}$ Manuscript submitted to Editorial Board September 6, 1983.

${ }^{2}$ Department of Botany, University of Nigeria, Nsukka. Financial assistance for this study was given by the Senate Research Grants Committee of the University of Nigeria, for which I am most grateful.

${ }^{3}$ Coursey, D. G. (1967), Yams. Longmans, London, 230 pp.

${ }^{4}$ Meyer, S. M., Anderson, D. B., Bohning, R. H., Fratianne, D. G. (1973). Introduction to Plant Physiology. D. Van Nostrand Company, London, pp 512-514.

${ }^{5}$ Passam, H. C. (1977), Sprouting and apical dominance of yam tubers. Tropical Science, $19(1), 29-39$. 
apical dominance. Since repeated observations by the author of this paper show that yam tubers appear to behave quite differently from the views expressed by the previous workers, experiments were undertaken to investigate the nature of shoot dominance in sprouting yam tubers.

This paper presents the results of experiments carried out over two storage seasons to study the true nature of shoot dominance in sprouting white yam tubers.

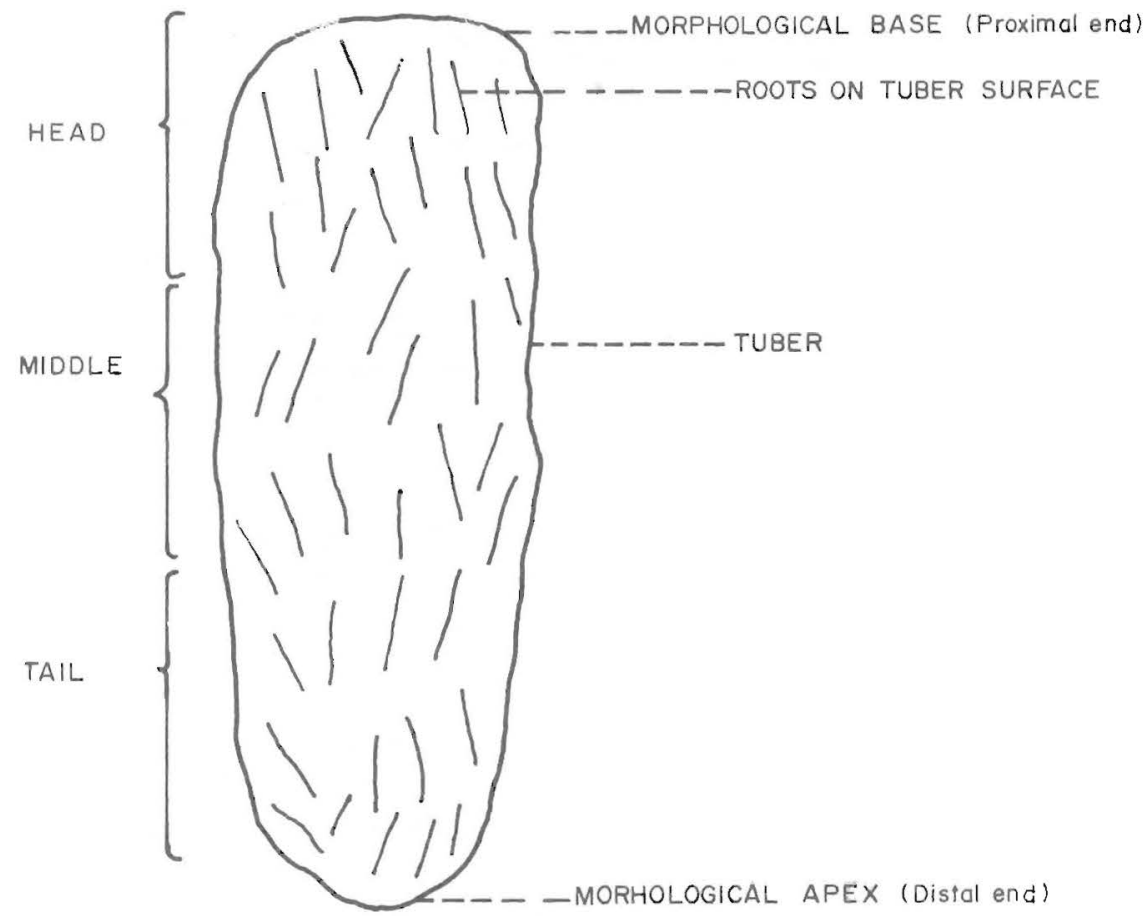

FIG. 1.-General morphology of the yam tuber: Dioscorea rotundata Poir (White yams).

\section{MATERIALS AND METHODS}

White yams (Dioscorea rotundata Poir.) used in these studies were planted in the Botanical Garden, University of Nigeria, Nsukka, in March 1979 and March 1980, respectively. Yams were harvested in November 1979 and November 1980 of each crop year of study. The study was carried out for two storage seasons beginning in November. Tubers of average weight of $600 \pm 5 \mathrm{~g}$ each were used. There were 50 intact tubers and 50 sectioned tubers stored in the conventional barn at tropical ambient temperatures. All tubers used were sprout free and rot free. In the case of sectioned tubers each tuber was cut into three pieces of equal 


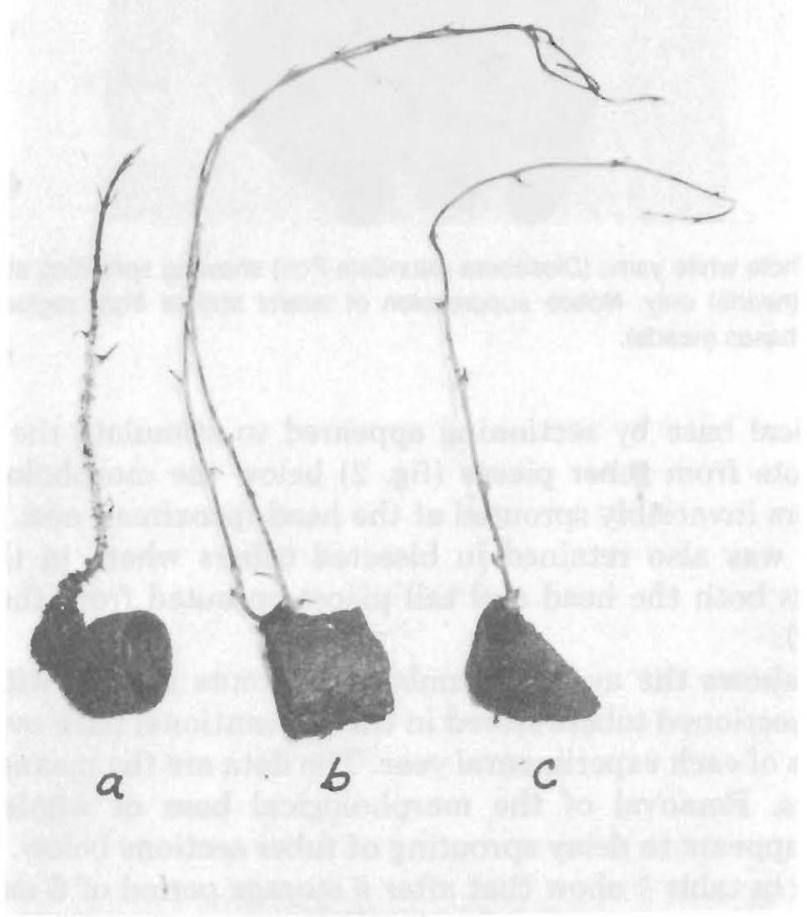

FIG. 2.-Growth of yam sprouts (Dioscorea rotundata Poir) from surfaces of sectioned tubers (photograph taken after 14 weeks of storage). Notice the release of lateral shoots in sections (b) and (c). (a) Proximal or basal region or head region; (b) Middle or intermediate region of tuber; (c) Distal region or apical region or tail region of tuber.

lengths (fig. 2) representing the proximal (head), middle, and distal (tail) regions. Sectioned tubers were "cured" by coating cut surfaces with wood ash before storing to prevent molding and rotting. ${ }^{6}$ The experiment was discontinued after 6 months (i.e. November-May) of each year when tubers had shown $100 \%$ sprouting.

\section{RESULTS}

In whole tubers (i.e. tubers not sectioned) sprouting occurred only at the morphological base or the proximal end (fig. 3). Removal of the

${ }^{6}$ Martin, F. W., 1974, Effects of Type of Wound, Species, and Humidity on Curing of Yam (Dioscorea alata L.) Tubers before Storage. J. Agric. Univ. P. R., 58 (2): 211-218. 


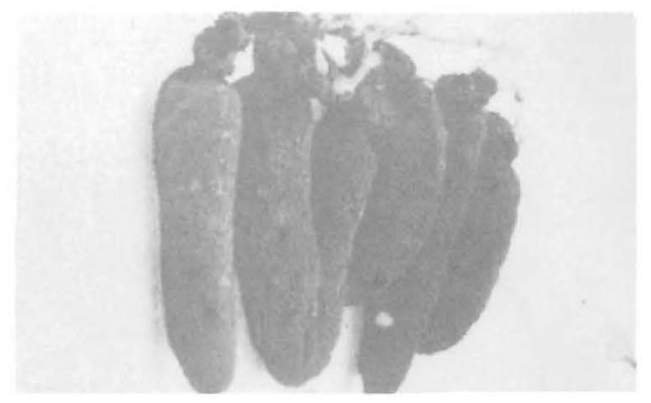

FIG. 3.-Whole white yams (Dioscorea rotundata Poir) showing sprouting at the morphological bases (heads) only. Notice suppression of lateral shoots from regions below the morphological bases (heads).

morphological base by sectioning appeared to stimulate the growth of lateral shoots from tuber pieces (fig. 2) below the morphological base. Intact tubers invariably sprouted at the head (proximal) end. This basal dominance was also retained in bisected tubers where in the present experiments both the head and tail pieces sprouted from the proximal ends (fig. 2).

Table 1 shows the average number of sprouts formed with time, in whole and sectioned tubers stored in the conventional barn over a period of 6 months of each experimental year. The data are the means of 2 years experiments. Removal of the morphological base of whole tuber by sectioning appears to delay sprouting of tuber sections below.

The data in table 1 show that after a storage period of 6 months only one sprout developed in the "head" section or proximal section of the tuber. The middle and the tail regions developed more sprouts than the head regions. The intact or whole tubers developed only one proximal sprout per tuber.

\section{DISCUSSION}

The nature of shoot dominance in yam tubers (Dioscorea rotundata Poir) seems not to be apical but basal. It is basal in the sense that in the intact or whole tubers (fig. 3) sprouts are formed only at the basal or proximal ends and no sprouts appear at the distal ends or morphological apex of each tuber. In whole tubers sprouting is proximal in nature and usually one in number, and this proximal sprout suppresses development of lateral sprouts along the tuber axis. But on the separation of this proximal sprout lateral sprouts develop below (fig. 2).

The present study therefore raises the question of the more appropriate terminology that should be used to describe the nature of shoot dominance found in yam tubers of the Dioscoreaceae family. 
TABLE 1.-Number of sprout development in whole and sectioned white yam tubers (Discorea rotundata Poir.) during storage in the conventional barn (2-year means \pm S.E.)

\begin{tabular}{|c|c|c|c|c|c|c|c|c|c|c|c|c|}
\hline \multirow{2}{*}{$\begin{array}{c}\text { Yam } \\
\text { sections }\end{array}$} & \multirow[b]{2}{*}{2} & \multirow[b]{2}{*}{4} & \multirow[b]{2}{*}{6} & \multirow[b]{2}{*}{8} & \multirow[b]{2}{*}{10} & \multirow[b]{2}{*}{12} & \multicolumn{6}{|c|}{ Weeks of storage } \\
\hline & & & & & & & 14 & 16 & 18 & 20 & 22 & 24 \\
\hline & & & & & & & \multicolumn{6}{|c|}{ Average number of sprouts per section } \\
\hline Proximal & - & - & - & - & - & - & $1.0 \pm 0.00$ & $1.0 \pm 0.00$ & $1.0 \pm 0.00$ & $1.0 \pm 0.00$ & $1.0 \pm 0.00$ & $1.0 \pm 0.00$ \\
\hline Middle & - & - & - & - & - & - & $2.5 \pm 0.7$ & $3.0 \pm 0.0$ & $4.5 \pm 0.7$ & $7.5 \pm 0.07$ & $7.5 \pm 0.07$ & $7.5 \pm 0.07$ \\
\hline Distal & - & - & - & - & - & - & $1.0 \pm 0.0$ & $2.5 \pm 0.7$ & $3.0 \pm 0.0$ & $5.5 \pm 0.7$ & $6.0 \pm 0.0$ & $6.0 \pm 0.0$ \\
\hline Whole & - & - & - & - & - & - & $1.0 \pm 00$ & $1.0 \pm 00$ & $1.0 \pm 00$ & $1.0 \pm 00$ & $1.0 \pm 0.00$ & $1.0 \pm 0.00$ \\
\hline
\end{tabular}


At the break of dormancy during storage in whole tuber, sprouting invariably occurs at the head-region (i.e. proximal or basal region); and while the head-sprout remains, sprouting in the middle (i.e. intermediate region) or tail-region (i.e. distal or apical region) of the tuber is suppressed. However, middle and tail portions of the tuber are able to sprout when severed from the head (table 1). When any yam section sprouts (tail, middle or head), the sprout tends to arise from the headward (more mature) part of the section (fig. 2). This more mature part of the tuber section is the proximal end of the section. When a mature whole or intact yam tuber sprouts, the situation is the same - a sprout is formed only at the head or proximal region of the tuber which is the most mature part of the intact yam tuber, whereas the middle or intermediate and the distal or apical regions are devoid of sprouts. This appears to be a true phenomenon of "basal dominance" being exhibited by intact or whole yam tuber at the break of dormancy.

In this paper a distinction is made between apical and basal dominance which are physiological phenomena of considerable importance in interpreting the behaviour of yams in storage. In both cases, it is the uppermost bud that inhibits lower buds. The physiological control is likely to be the same, via auxin.

This is apparently the first time that such a distinction has been reported in the post harvest physiology of the yam tuber in storage.

\section{RESUMEN}

La naturaleza de la dominancia en la brotación de los tubérculos del ñame (Dioscorea rotundata Poir) se estudió en condiciones ambientales en un tinglado corriente para almacenar ñames. Los tubérculos enteros brotaron en el extremo proximal, o sea en la base morfológica o extremo en que el tubérculo esta adherido al tallo. El único vástago que brota en un ñame entero inhibe la brotación de otros vástagos a lo largo del eje del tubérculo. Si el tubérculo se corta en tres secciones: "cabeza" (región basal or proximal), "medio" y "rabo" (región apical o distal) se estimula la brotadura de vástagos laterales en la superficie debajo de la región basal. Al separar la región basal desaparece la tensión que impedía que los vástagos laterales brotaran en el tubérculo entero. Esto indica una fuerte dominancia basal sobre los brotes basales en el tubérculo entero.

La fisiología de la dominancia en tubérculos enteros podría describirse como "dominancia basal" en vez Je "dominancia apical", ya que en la brotadura de un tubérculo entero, $\epsilon \mathrm{s}$ el brote basal (el de la base morfológica o extremo proximal) el que inh be el desarrollo de brotes laterales a lo largo del eje del tubérculo. 